\title{
DECISION TREE DALAM MENGKLASIFIKASI MATA KULIAH TERHADAP PEMAHAMAN SISTEM PEMASARAN
}

\author{
Aslam Fatkhudin ${ }^{*}$, Akhmad Khambali², Fenilinas Adi Artanto ${ }^{3}$ \\ ${ }^{1}$ Manajemen Informatika / Fastikom / Universitas Muhammadiyah Pekajangan Pekalongan \\ ${ }^{2}$ Manajemen Informatika / Fastikom / Universitas Muhammadiyah Pekajangan Pekalongan \\ ${ }^{3}$ Informatika / Fastikom / Universitas Muhammadiyah Pekajangan Pekalongan \\ *email: aslamfatkhudin@umpp.ac.id
}

\begin{abstract}
ABSTRAK
Dengan maraknya aplikasi-aplikasi pendukung proses jual beli atau lebih dikenal e-commerce, dan saat ini jualbeli secara daring menjadi trend dikalangan mahasiswa, dan juga menjadi sumber penghasilan yang bisa dilakukan diwaktu senggang, oleh karena itu untuk dapat meningkatkan hasil dari penggunaan e-commerce diperlukan pemahaman tentang sistem pemasaran. Dalam penelitian ini dilakukan penelitian tentang mata kuliah apa saja yang di ajarkan kepada mahasiswa di Fakultas Teknik dan Ilmu Komputer Universitas Muhammadiyah Pekajangan Pekalongan yang akan membantu dalam pemahaman tentang sistem pemasaran. Digunakan algoritma klasifikasi C4.5 untuk membangun pohon keputusan (Decision Tree) yang akan memudahkan dalam melihat mata kuliah yang dapat digunakan untuk memahami sistem pemasaran. Setelah dilakukan analisis didapatkan mata kuliah kewirausahaan, sistem informasi manajemen, analisa design dan sistem informasi, komunikasi data dan jaringan komputer, organisasi komputer dan algoritma dan pemrograman terstruktur yang nantinya dapat digunakan dalam memperoleh pemahaman tentang sistem pemasaran.
\end{abstract}

Kata Kunci : Decesion Tree, C4.5, Klasifikasi

\section{ABSTRACT}

With the proliferation of applications that support the buying and selling process or better known as e-commerce, and currently online buying and selling is a trend among students, and also a source of income that can be done in spare time, therefore to be able to increase the results of using e-commerce. -commerce required an understanding of the marketing system. In this study, research was conducted on what subjects were taught to students at the Fakultas Teknik dan Ilmu Komputer, Universitas Muhammadiyah Pekajangan Pekalongan which would help in understanding the marketing system. The C4.5 classification algorithm is used to build a decision tree that will make it easier to see courses that can be used to understand the marketing system. After the analysis, the subjects of entrepreneurship, management information systems, design analysis and information systems, data communication and computer networks, computer organization and algorithms and structured programming can be used to gain an understanding of marketing systems.

Keywords: Decesion Tree, C4.5, Classification. 


\section{PENDAHULUAN}

Kondisi saat ini yang sudah memasuki era industri 4.0 dan juga dengan adanya kemajuan teknologi yang semakin mumpuni, maka banyak hal sudah mulai menggunakan kemajuan teknologi seperti halnya internet. Dalam urusan jual belipun sudah marak aplikasi-aplikasi pendukung seperti halnya $e$ commerce. Oleh karena itu sekarang banyak mahasiswa ataupun ibu-rumah tangga yang mengisi waktu luangnya dengan berdagang secara online. Dalam berdagang ataupun aktivitas jual beli juga diperlukan pemahaman tentang pemasaran. Pemasaran adalah sistem keseluruhan dari kegiatan usaha yang ditunjukan untuk merencanakan, menentukan harga, mempromosikan dan mendistribusikan barang dan jasa yang dapat memuaskan kebutuhan pembeli [1]. Terutama untuk para lulusan maupun mahasiswa dari perguruan tinggi tentunya perlu melengkapi dirinya dengan ketrampilan-ketrampilan tentang pamasaran dalam era modern ini. Dengan adanya banyaknya mata kuliah yang sudah diberikan dalam proses pembelajaran mahasiswa di perguruan tinggi kiranya mana saja mata kuliah yang akan mendukung mahasiswa dalam menguasai dan memahai tentang aplikasi pemasaran dalam sistem pemasaran. Data dikumpulkan dari para mahsiwa dan akan dianalisi dengan menggunkan metode pohon keputusan atau decission tree, yang merupakan metode yang dapat mengubah fakta menjadi pohon keputusan yang merepresentasikan aturan-aturan yang mudah dipahami [2]. Dengan melihat hasil dari pohon keputusan maka akan semakin memudahkan untuk melihat mata kuliah apa saja yang memang dibutuhkan untuk memahami aplikasi pemasran dalam sistem pemasaran usaha.

\section{TINJAUAN PUSTAKA}

\subsection{Pemasaran}

Pemasaran merupakan sebuah faktor dalam siklus pemenuhan kebutuhan kosnumen. Pemasaran merupakan sistem keseluruhan dari kegiatan usaha yang ditujukan untuk merencanakan, mempromosikan dan mendistribusikan barang dan jasa yang dapat memuaskan kebutuhan pembeli [3]. Agar pemuasan konsumen dapat dilakukan maka sebaiknya pemasaran sebagi konsep bisnis dapat memberikan kepuasan yang berkelanjutan bukan hanya bagi pemilik tetapi juga untuk konsumen [4]. Oleh karena itu apakah materi materi perkuliaha yang sudah diambil oleh mahasiswa dapat mereka gunakan sebagai strategi pemasaran karena strategi pemasaran harus dibuat situasi dan keadaan dan dapat bersaing dengan baik.

\subsection{Data Mining}

Data mining adalah proses menemukan pengetahuan yang ditambang dari kumpulan data dengan jumlah besar [5]. Selain itu data mining juga dapat diartikan sebagai proses menggunakan teknik atau metode tertentu untuk menemukan pola atau informasi yang menarik dalam data yang dipilih, menggunakan teknik atau metode tertentu [6]. Sebenarnya data mining merupakan langkah dalam membersihkan, mengintegrasi, memilih, mentransformasi dan mengevaluasi pengetahuan atau informasi dari data [7]. Terdapat beberapa jenis aplikasi atau software yang digunakan dalam data mining seperti Rapidminer, Weka, Orange, KNIME, SPSS Climatte dan lain sebagainya. Lalu pada penelitian ini nantinya akan digunakan Rapidminer dikarenakan Rapidminer mudah digunakan dan tidak membingungkan dengan penggunaan bahasa pemrograman yang sulit [6].

\subsection{Klasifikasi}

Salah satu kemampuan dari data mining adalah mengklasifikasi data. Klasifikasi merupakan teknik penambangan data yang memetakan data ke dalam kelompok atau kelas ang telah ditentukan [8]. Dalam mengklasifikasi data terdapat banyak metode seperti pohon keputusan, bayes, jaringan syaraf tiruan, analisis statistik, algoritma genetik, suport vector machine (SVM), dan masih banyak lainya. Metode yang populer dalam mengklasifikasi data adalah pohon keputusan karena mudah dalam penggunaanya.

\subsection{Pohon Keputusan}

Metode pohon keputusan atau decision tree, merupakan sebuah metode yang dapat mengubah fakta yang sangat besar menjadi sebuah pohon keputusan yang nerepresentasikan aturan. Aturan yang ditampilkanya dapat dengan mudah dipahami [2]. Banyak algoritma yang bisa digunakan dalam pembentukan pohon keputusan, antara lain ID3, CART, dan C4.5. Algoritma C4.5 sendiri merupakan pengembangan dari algoritma ID3.

\subsection{Algoritma C.4.5}

Salah satu algoritma yang sering digunakan untuk membuat pohon keputusan adalah C4.5, dikarenakan merupakan algortima yang populer dikalangan para peneliti. Pohon keputusan mirip sebuah struktur pohon dimana terdapat node yang mendeskripsikan atribut, setiap cabang menggabarkan hasil dari atribut yang diuji dan setiap daun menggambarkan kelas [9]. Secara umum algoitma C4.5 dalam membangun pohon keputusan adalah sebagi berikut [2]:

a. pilih atribut sebagai akar

b. buat cabang untuk tiap nilai

c. bagi kasus dalam cabang

d. ulangi proses untuk setiap cabang sampai semua kasus pada cabang memiliki kelas yang sama untuk memilih atribut akar, didasarkan pada nilai gain tertinggi dari atribut yang ada. Untuk menghitung gain maka digunakan rumus berikut [10]:

$$
\operatorname{Gain}(S . A)=\text { Entropy }(S)-\sum_{i=1}^{n} \frac{\left|S_{i}\right|}{|S|} \text { Entropy } S_{i}
$$


Dimana:

$$
\begin{array}{ll}
\mathrm{S} & =\text { Himpunan kasus } \\
\mathrm{A} & =\text { Atribut } \\
\mathrm{N} & =\text { Jumlah partisi atribut A } \\
|\mathrm{Si}| & =\text { Jumlah kasus pada partisi ke-i } \\
|\mathrm{S}| & =\text { Jumlah kasus dalam S }
\end{array}
$$

\section{METODE YANG DIUSULKAN}

\subsection{Data}

Data yang digunakan dalam penelitian ini adalah data dari para Mahasiswa FASTIKOM UMPP yang meliputi Mata Kuliah yang diberikan pada mahasiswa Fastikom UMPP terutamanya untuk jurusan D3 Manajemen Informatika dan pemahaman penggunaan aplikasi pemasaran pada periode Maret - April 2021.

\subsection{Sumber Data}

Dari para mahasiswa FASTIKOM UMPP Prodi Diploma Tiga Manajemen Informatika berkisar 30'an Mahasiswa.

\subsection{Populasi dan Sampel}

Populasi yang digunakan dalam penelitian ini adalah mahasiswa FASTIKOM UMPP Program Studi D3 Manajemen Informatika. Dalam penelitian ini menetapkan batasan-batasan yang sesuai dengan masalah penelitian sehingga didapatkan sampel yang sesuai. Batasan-batasan yang ditetapkan oleh peneliti adalah sebagai berikut:

1. Sampel yang diambil hanya para mahasiswa Fastikom UMPP Program Studi D3 Manajemen Informatika.

2. Variabel yang dihitung hanya meliputi mata kuliah, dan pemahaman penggunaan aplikasi pemasaran (Y)

3. Periode pengambilan data dimulai dari bulan Maret 2021 sampai April 2021

Setelah google form dibagikan didapatkan data dari mahasiswa Program Studi Manajemen Informatika pada Fakultas Teknik dan Ilmu Komputer, Universitas Muhammadiyah Pekajangan Pekalongan yang terdiri dari 11 mahasiwa yang sudah lulus dan 29 mahasiwa yang masih aktif kuliah. Dengan kriteria penilaian skala 1-5 dengan 1 (belum mengambil makul), 2 (tidak memahami makul tersebut), 3 (sedikit memahami makul tersebut), 4 (memahami makul tersebut) dan 5 (sangat memahami makul tersebut).

\subsection{Definisi Operasional Variabel}

1. Variabel Dependen

Dalam penelitian ini dipilih variabel dependen untuk data Pemahaman penggunaan aplikasi pemasaran (Y).

2. Variabel Independen

Variabel independen dalam penelitian ini adalah . materi perkuliahan mahasiswa D3 Manajeman Informatika Fastikom UMPP (X).

\subsection{Evaluasi Model}

Dalam mengevaluasi model digunakan algoritma C4.5 yang nantinya akan dibantu oleh aplikasi rapidminer. Dengan rapidminer dan pemilihan algoritma C4.5 maka nantinya akan terlihat seberapa besar akurasi algoritma dan bentuk dari pohon keputusan yang dibuat.

\section{ANALISIS DAN PEMBAHASAN}

\subsection{Klasifikasi C.4.5}

Dari 40 data yang sudah dikumpulkan dilakukan analsis dengan menggunakan program rapidminer dan dipilih algoritma C.4.5 sebagai model klasifikasi dan mendapatkan hasil pohon keputusan seperti berikut ini:

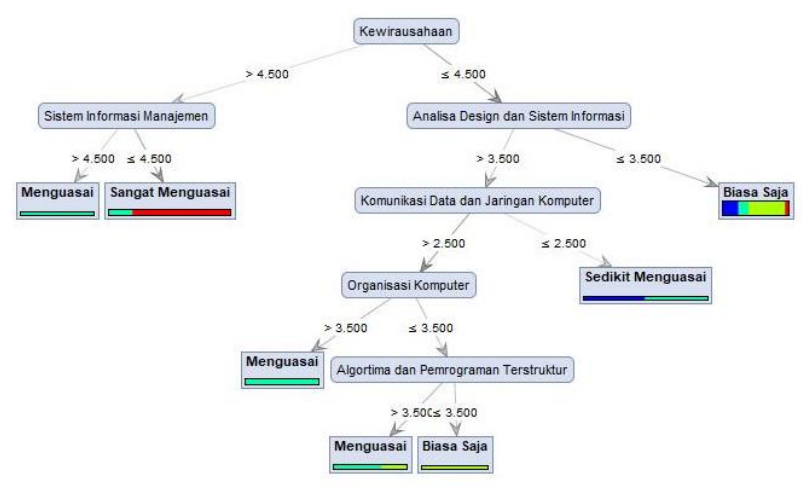

Gambar 1. Hasil Pohon Keputusan

dari gambar keputusan terlihat bahwa ada 5 arah yang bisa dipahami, dan juga terlihat bahwa kewirausahaan menjadi mata kuliah yang terpenting dalam memahami sistem pemasaran. Selain bentuk pohonya juga tersedia model text seperti berikut:

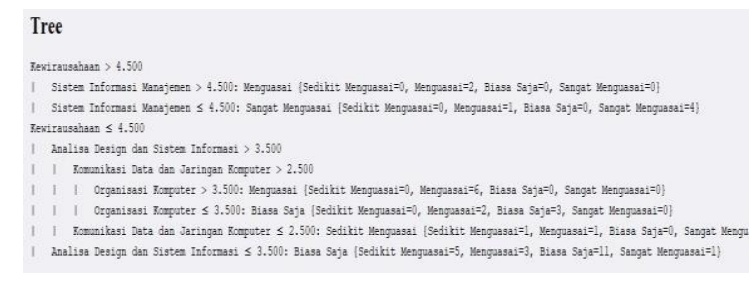

Gambar 2. Ouput Text Pohon Keputusan

Selain pohon keputusan hasil dari akurasi algoritma C.4.5 juga didapatkan sebagai berikut:

Tabel 1. Akurasi C.4.5

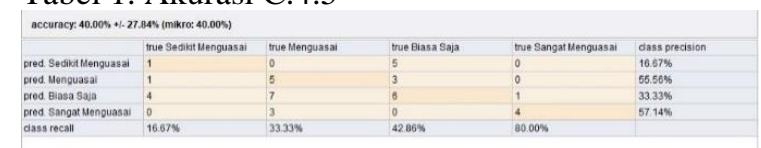

dari tabel terlihat bahwa akurasi algoritma C.4.5 hanya mampu memberikan akurasi sebesar $40 \%$ saja. 


\subsection{Pembahasan}

Pada pohon keputusan terlihat mata kuliah kewirausahaan menjadi mata kuliah utama, dan selain itu juga terdapat 7 cabang, yang dapat dijelaskan seperti berikut ini:

1. Cabang 1 yaitu jika mahasiswa sangat memahami mata kuliah kewirausahaan dan sangat memahami sistem informasi manajemen akan dapat sangat menguasai tentang sistem pemasaran,

2. Cabang 2 yaitu jika mahasiswa sangat memahami mata kuliah kewirausahaan dan memahami sistem informasi manajemen maka mahasiswa dapat menguasai sistem pemasaran.

3. Cabang 3 yaitu jika mahasiswa memahami mata kuliah kewirausahaan dan tidak memahami mata kuliah analisa design dan sistem informasi maka mahasiswa hanya bisa saja dalam menguasai sistem pemasaran.

4. Cabang 4 yaitu jika mahasiswa memahami mata kuliah kewirausahaan, sedikit memahami mata kuliah analisa design dan sistem informasi, dan tidak memahami mata kuliah komunikasi data dan jaringan komputer, maka mahasiswa hanya akan sedikit menguasai sistem pemasaran.

5. Cabang 5 yaitu jika mahasiswa memahami mata kuliah kewirausahaan, sedikit memahami mata kuliah analisa design dan sistem informasi, sedikit memahami mata kuliah komunikasi data dan jaringan komputer, dan memahami mata kuliah organisasi komputer maka mahasiswa akan menguasai sistem pemasaran.

6. Cabang 6 yaitu jika mahasiswa memahami mata kuliah kewirausahaan, sedikit memahami mata kuliah analisa design dan sistem informasi, sedikit memahami mata kuliah komunikasi data dan jaringan komputer, memahami mata kuliah organisasi komputer, dan memahami mata kuliah algoritma dan pemrohraman terstruktur maka mahasiswa akan menguasai sistem pemasaran.

7. Cabang 6 yaitu jika mahasiswa memahami mata kuliah kewirausahaan, sedikit memahami mata kuliah analisa design dan sistem informasi, sedikit memahami mata kuliah komunikasi data dan jaringan komputer, memahami mata kuliah organisasi komputer, dan sedikit memahami mata kuliah algoritma dan pemrohraman terstruktur maka mahasiswa akan biasa saja dalam pemahaman sistem pemasaran.

Lalu hasil analisa dengan algoritma C.4.5 ini hanya memiliki nilai akurasi sebesar $40 \%$.

\section{KESIMPULAN}

Dari hasil klasifikasi dengan algoritma C.4.5 mata kuliah yang dibutuhkan untuk pemahaman dan penguasaan sistem pemasaran adalah Kewirausahaan, Sistem Informasi Manajemen, Analisa Design dan Sitem Informasi, Komunikasi Data dan Jaringan Komputer, Organisasi Komputer, dan mata kuliah
Algoritma dan Pemrograman Tersruktur dengan hasil akurasi dari algoritma C. 4.5 hanya $40 \%$.

\section{DAFTAR PUSTAKA}

[1] A. Priangani, "Memperkuat Manajemen Pemasaran Dalam Konteks," J. Kebangs., vol. 2, no. 4, pp. 1-9, 2013.

[2] Y. Mardi, "Data Mining: Klasifikasi Menggunakan Algoritma C4.5," J. Edik Inform., vol. 2, no. 2, pp. 213-219, 2017.

[3] H. Winarto and Chandra, "Strategi pemasara," Maj. Ilm. Ekon., vol. 14, no. 1, pp. 124-128, 2002.

[4] D. A. N. Implikasinya, "Perkembangan Konsep Pemasaran: Implementasi," $J$. MAKSIPRENEUR, vol. III, no. 1, pp. 21-35, 2013.

[5] J. Han and M. Kamber, Mining Stream, TimeSeries and Sequence Data, vol. 54. 2006.

[6] Ainurrohmah, "Akurasi Algoritma Klasifikasi pada Software Rapidminer dan Weka," Prisma, vol. 4, pp. 493-499, 2021, [Online]. Available:

https://journal.unnes.ac.id/sju/index.php/pris mal.

[7] M. Ayub, "Proses Data Mining dalam Sistem Pembelajaran Berbantuan Komputer," no. May, pp. 21-30, 2018.

[8] S. Bahri, A. Lubis, U. Pembangunan, and P. Budi, "Metode Klasifikasi Decision Tree Untuk Memprediksi Juara English Premier League," Sintaksis, vol. 2, no. 04, pp. 63-70, 2020.

[9] A. H. Nasrullah, "Penerapan Metode C4.5 untuk Klasifikasi Mahasiswa Berpotensi Drop Out," Ilk. J. Ilm., vol. 10, no. 2, pp. 244-250, 2018, doi: 10.33096/ilkom.v10i2.300.244250.

[10] E. Elisa, "Analisa dan Penerapan Algoritma C4.5 Dalam Data Mining Untuk Mengidentifikasi Faktor-Faktor Penyebab Kecelakaan Kerja Kontruksi PT.Arupadhatu Adisesanti," J. Online Inform., vol. 2, no. 1, p. 36, 2017, doi: 10.15575/join.v2i1.71. 